\title{
Wsparcie psychologiczno-pastoralne wobec osób uzależnionych od alkoholu
}

Obliczenia Światowej Organizacji Zdrowia [dalej: WHO] wskazują, że obecnie na świecie alkohol spożywa ok. 2 mld ludzi. Jest to więc 25 proc. wszystkich obywateli. Aż $76 \mathrm{mln}$ we wspomnianej grupie pijących jest dotkniętych różnymi problemami związanymi ze spożywaniem alkoholu. W Polsce substancji tej nadużywa 3 mln obywateli. Biorąc pod uwagę także rodziny alkoholików, liczba osób dotkniętych w jakiś sposób przez alkohol sięga do $12 \mathrm{mln}^{2}$. Substancję tę spożywają w Polsce również nieletni. Prawie 250 tys. nastolatków upija się regularnie. Badania wykazują, że piwo pije 70 proc. chłopców i 67 proc. dziewcząt; wino 69 proc. chłopców i 36 proc. dziewcząt; wódkę odpowiednio 14 proc. i 7 proc. Na podstawie badań wiadomo, że około 10 proc. nadużywających alkoholu staje się alkoholikami. W Polsce odsetek ten jest wyższy i wynosi 22 proc. $^{3}$

1 Jan Dziedzic - ks. dr hab., prof. UPJPII, kierownik Katedry Psychologii Pastoralnej na Wydziale Teologicznym Uniwersytetu Papieskiego Jana Pawła II w Krakowie. Kierownik Uniwersytetu Trzeciego Wieku przy UPJPII. Jego badania naukowe koncentrują się wokół psychologii pastoralnej i tanatologii.

2 Por. A. Szwedzik, Destrukcyjne skutki alkoholizmu w obszarze osobowo-moralno-społecznym oraz sposoby przeciwdziałania, "Częstochowskie Studia Teologiczne" 41 (2013), s. 169-170.

3 Por. J. Sokołowski, Choroba alkoholowa i jej wpływ na stwierdzenie nieważności małżeństwa, „tódzkie Studia Teologiczne” 22 (2013), s. 179. 
Nadużywanie alkoholu w Polsce nie jest czymś nowym. Ma ono swoją historię. W 1836 roku w Galicji czynnych było prawie 5 tys. gorzelni, wytwarzających ponad 600 tys. hektolitrów stuprocentowego spirytusu, co stanowiło połowę całej produkcji cesarstwa. $\mathrm{Na}$ jednego mieszkańca przypadało wtedy 15 litrów czystego spirytusu. Sytuacja w Królestwie Polskim nie była lepsza. Tu na jednego mieszkańca przypadało 12 litrów spirytusu ${ }^{4}$. W tym czasie statystyczny Polak wypijał także 100 litrów piwa.

Statystyki przybliżające postawy Polaków wobec alkoholu wyraźnie dowodzą, że nadużywanie go jest faktem. $Z$ tym wiążą się negatywne konsekwencje zarówno wobec jednostki, jak i społeczeństwa. Nie można tu pominąć rodziny, która niejednokrotnie musi borykać się z chorobą alkoholową jednego ze swoich członków, co prowadzi do wielkiego bólu i cierpienia oraz niesie ze sobą zdrowotne konsekwencje na przyszłość, zwłaszcza dla dzieci.

Prezentowany artykuł, uwzględniając powyższy kontekst, przybliża problematykę alkoholizmu $\mathrm{w}$ aspekcie psychologiczno-pastoralnym. Najpierw zostanie wyjaśnione, na czym polega uzależnienie od alkoholu, następnie omówimy poszczególne etapy pomocy terapeutyczno-duszpasterskiej wobec uzależnionych, na koniec zajmiemy się zaś profilaktyką i wskażemy na formację do trzeźwości, będącą istotnym elementem wychowania do życia bez nadużywania alkoholu.

\section{Uzależnienie od alkoholu}

Według Wielkiego słownika języka polskiego uzależnienie to „silne przyzwyczajenie, zmuszające do regularnego zażywania szkodliwej

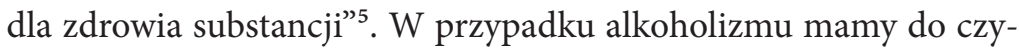

4 Por. K. Bielawny, Ruch trzeźwości w diecezji warmińskiej w latach 1884-1945, „Forum Teologiczne" 6 (2005), s. 121.

5 http://www.wsjp.pl/index.php?id_hasla=29221\&id_znaczenia $=4797275 \& \mid=29$ (6.12.2015). 
nienia ze stanem psychicznej i fizycznej zależności od alkoholu, przejawiającym się okresowym lub stałym upijaniem się. Z uzależnieniem od alkoholu związane są jakieś uwarunkowania, na które składają się przyczyny i w konsekwencji następstwa podjętych wcześniej działań.

\subsection{Pojęcie}

Alkohol to najstarszy i najpowszechniej używany środek odurzający. Bez wątpienia przynosi on negatywne skutki dla zdrowia, ponieważ jest trucizną, szkodliwą dla układu nerwowego, psychiki i całego organizmu. Mimo tego nie brakuje osób, które nie wyobrażają sobie udanego przyjęcia bez wypicia go. Do najbardziej znanych i powszechnie używanych napojów alkoholowych zalicza się: koniaki, brandy, wódki, koktajle, szampany, wina i piwa. Wśród alkoholi wymienia się także różne nalewki spirytusowe: likiery, rum, arak, bimber, samogon pospolite wina owocowe. Popularność alkoholu i równocześnie jego szkodliwość sprawiają, że znajduje się on na trzecim miejscu wśród czynników ryzyka dla zdrowia ludzkiego, a nałóg picia alkoholu jest jednym z najbardziej rozpowszechnionych uzależnień na świecie 6 .

Sam termin „alkoholizm” został wprowadzony przez szwedzkiego lekarza Magnusa Hussa i po raz pierwszy użyty w 1849 roku. Na liście chorób umieściła go WHO w roku $1956^{7}$. Zgodnie z definicją WHO uzależnienie od alkoholu to

stan psychiczny i fizyczny wynikający ze współdziałania żywego organizmu i alkoholu. Stan ten charakteryzuje się zmianami w zachowaniu

6 Por. C. Cekiera, Alkoholizm, [w:] Encyklopedia bioetyki. Personalizm chrześcijański. Głos Kościoła, red. A. Muszala, Radom 2005, s. 33.

7 Por. M. Majewski, Używanie napojów alkoholowych zagadnieniem moralnym. Przyczynek do duszpasterstwa trzeźwości, „Perspectiva. Legnickie Studia Teologiczno-Historyczne” 2 (2003) nr 1 (2), s. 198-199. 
i innymi następstwami, w tym zawsze przymusem ciągłego lub okresowego używania alkoholu po to, aby doświadczyć psychicznych efektów jego działania lub aby uniknąć objawów wynikających z jego braku, takich jak złe samopoczucie ${ }^{8}$.

Człowiek może uzależnić się równolegle od alkoholu i innych środków.

W podręczniku Amerykańskiego Towarzystwa Psychiatrycznego pt. Diagnostic and statistical manual of mental disorders (DSM-III) uzależnienie od alkoholu zostało wyróżnione jako osobna kategoria zaburzeń wynikających z nadużywania środków odurzających. Za kryteria występowania uzależnienia od alkoholu uznano:

patologiczny wzorzec używania alkoholu lub zaburzenie funkcji społecznych i zawodowych, które spowodowane zostały używaniem alkoholu, oraz towarzysząca któremuś z nich zmieniona tolerancja bądź objawy zespołu abstynencyjnego ${ }^{9}$.

Obowiązująca obecnie w Polsce definicja choroby alkoholowej powstała w 1992 roku. Wtedy została zmieniona nazwa „alkoholizm” na „zespół uzależnienia od alkoholu”, który jest definiowany jako: „zespół objawów somatycznych, behawioralnych i poznawczych, w których picie alkoholu staje się priorytetowe nad innymi, poprzednio ważniejszymi zachowaniami”. Zgodnie z powyższą definicją choroby do jej zdiagnozowania konieczne jest wystąpienie w ciągu roku trzech spośród sześciu objawów alkoholizmu. Zaliczają się do nich: 1) silna potrzeba - głód picia alkoholu, 2) występowanie tolerancji alkoholowej - coraz słabsza reakcja na tę samą ilość alkoholu (uodparnianie), 3) zespół abstynencyjny lub naprzemienne spożywanie alkoholu i środków o podobnym

8 B. T. Woronowicz, Alkoholizm jest choroba, Warszawa 1998, s. 62-63.

9 B. T. Woronowicz, Alkoholizm jako choroba, Warszawa 1995, S. 52. 
działaniu, 4) ograniczenie możliwości kontroli nad zachowaniami związanymi ze spożywaniem alkoholu, 5) picie alkoholu mimo wiedzy o jego szkodliwości, 6) zaniedbywanie innych zainteresowań i przyjemności ${ }^{10}$.

\subsection{Uwarunkowania choroby alkoholowej}

Na podstawie badań Programu Aktywizacji Placówek Odwykowych ${ }^{11}$ można stwierdzić, że alkoholicy spotykają się z takimi problemami jak: 1) zaburzenia życia rodzinnego - 94 proc., 2) problemy w kontaktach z ludźmi -84 proc., 3) problemy finansowe -82 proc., 4) przemoc wobec bliskich - 57 proc., 5) problemy z prawem (karalność) - 51 proc. Wyniki te wskazują na skutki nadużywania alkoholu. Zanim do nich jednak dojdzie, wcześniej jest wiele przyczyn powstania nałogu.

\subsubsection{Przyczyny}

Ogólnie rzecz biorąc, wyróżnia się kilka podstawowych przyczyn powodujących uzależnienie od alkoholu. Zaliczamy do nich czynniki: biologiczne, psychiczne, społeczne i duchowe. Przyjmuje się, że możliwe jest odziedziczenie pewnych predyspozycji do powstawania uzależnienia. Badania wskazują na bardzo istotny wskaźnik w jego rozwoju, jakim jest wpływ środowiska rodzinnego. Mianowicie wskutek negatywnego i długotrwałego oddziaływania najbliższego otoczenia dochodzi do ukształtowania się tzw. osobowości przednałogowej ${ }^{12}$. W oparciu o badania adoptowanych dzieci alkoholików można stwierdzić, że dzieci te czterokrotnie częściej popadają w alkoholizm niż osoby pochodzące z rodzin zdrowych. Wielokrotnie

\footnotetext{
10 http://www.bezuzaleznien.pl/definicje-alkoholizmu (7.12.2015).

11 http://gopswydminy.pl/przeciwdzialanie-uzaleznieniom/alkoholizm/alkoholizm-definicja (7.12.2015).

12 Por. J. Karpowicz, Paradygmaty psychoterapii, Warszawa 2003, s. 49-50.
} 
częstsze występowanie alkoholizmu zaobserwowano również u synów ojców uzależnionych ${ }^{13}$.

Uzależnienie od alkoholu można wyjaśniać także przez posiadanie pewnych cech osobowości ${ }^{14}$, które sprzyjają sięganiu po niego. Jest to negatywny obraz siebie, niedojrzałość emocjonalna, neurotyczność, wysokie natężenie lęku, depresyjność, histeryczność ${ }^{15}$. Na nadużywanie alkoholu może wpłynąć także: nasilony niepokój w kontaktach interpersonalnych, poczucie wyobcowania, perfekcjonizm oraz chwiejny stosunek do autorytetów ${ }^{16}$.

Przyczyn rozwoju uzależnienia upatruje się również w czynnikach społecznych. Szczególnie ważne znaczenie ma środowisko rodzinne. To ono może poprzez stworzenie korzystnych warunków ograniczyć ryzyko uzależnień swoich członków, może też je zwiększyć w przypadku niewłaściwych relacji w rodzinie. Mówi się tutaj o tzw. dziedziczeniu społecznym, polegającym na stosowaniu w życiu dorosłym norm i zwyczajów obowiązujących w domu rodziców. Potwierdzają to badania, z których wynika, że alkoholicy najczęściej pochodzą z rodzin, $\mathrm{w}$ których przynajmniej jedno $\mathrm{z}$ rodziców było alkoholikiem. Z rodzin, gdzie nie używano alkoholu, częściej wywodzili się abstynenci ${ }^{17}$.

13 Por. W. Bołoz, Uzależnienia i odpowiedzialność, „Studia nad Rodziną” 1998 nr 2, s. 83-92.

14 Por. A. Miklewska, A. Miklewska, Związek temperamentu z zachowaniami agresywnymi i zagrożeniem uzależnieniem od alkoholu w świetle regulacyjnej teorii temperamentu ]. Strelaua. Sprawozdanie z badań, „Przegląd Psychologiczny” 43 (2000) nr 2 , s. 173-190; E. Aronowska, A. Brustman, Uwarunkowania osobowościowe alkoholizmu, "Studia Psychologica UKSW" 2004 nr 5, s. 207-231.

15 Por. J. Mellibruda, Psychologiczna analiza funkcjonowania alkoholików i członków ich rodzin, Warszawa 1999, s. 20; K. Chojna, Formy działań profilaktycznych i interwencyjnych wobec seniorów nadużywających alkoholu, „Ateneum Kapłańskie” 2011 z. 1 (614), s. 85-86.

16 Por. J. Wołoszyn, Pomoc psychoterapeutyczna osobom uzależnionym od alkoholu, "Colloquia Theologica Ottoniana" 2011 nr 2, s. 133.

17 Por. B. T. Woronowicz, Alkoholizm jest chorobq, dz. cyt., s. 17. 
Z punktu widzenia społecznego ważną rolę odgrywa również dostępność napojów alkoholowych, tj. cena, łatwość ich nabycia czy też brak ograniczenia $\mathrm{w}$ ich sprzedaż $y^{18}$. Na powstawanie uzależnienia wpływają też postawy permisywne, pozwalające na picie. Oczywiście nie bez znaczenia jest grupa rówieśnicza, szkoła i zawód oraz mass media jako potencjalny wychowawca ${ }^{19}$.

Inna koncepcja poszukująca podłoża uzależnień wskazuje na egzystencjalne potrzeby człowieka. Do nadużywania alkoholu może przyczyniać się brak poczucia sensu życia oraz brak spełnionych potrzeb duchowych. Mówi się tutaj o celach wyższych i o tym, co nieosiągalne i niedostępne. Spożywanie alkoholu minimalizuje ten deficyt, dając tymczasowe poczucie wyższości i pewności siebie. Wpływa ono także, przynajmniej czasowo, na zmniejszenie lęku przed śmiercią ${ }^{20}$.

Podkreśla się tu rolę doświadczanych w życiu człowieka różnych kryzysów oraz brak odpowiedzi na pytania, kim jesteśmy i dokąd zmierzamy. Nie bez znaczenia jest kryzys systemu wartości i brak dojrzałej postawy wobec siebie oraz utrata nadrzędnego celu naszego istnienia określanego $\mathrm{w}$ wymiarze transcendentnym ${ }^{21}$. Alkohol ma za zadanie zneutralizować świadomość braku celów, cierpienie, i wypełnić poczucie pustki ${ }^{22}$.

\subsubsection{Następstwa}

Alkoholizm jest chorobą oddziaływującą na całego człowieka. Jest on przyczyną wielu problemów dotyczących samego uzależnionego,

Por. B. T. Woronowicz, Alkoholizm jest chorobq, dz. cyt., s. 17.

Por. W. Bołoz, Uzależnienia i odpowiedzialność, dz. cyt., s. 89-90.

Por. D. Pstrąg, Wybrane zagadnienia z problematyki uzależnień, Rzeszów 2000.

Por. M. Dziewiecki, Rola Kościoła w wychowaniu do wolności w kontekście integralnego spojrzenia na profilaktyke, "Studia nad Rodziną” 1998 nr 2, s. 111-122.

Por. I. Pospiszyl, Patologie społeczne, Warszawa 2009, s. 147. 
jego rodziny i szeroko rozumianego środowiska. Biorąc pod uwagę jednostkę, należy najpierw zauważyć konsekwencje zdrowotne, jakie niesie ze sobą nadużywanie alkoholu. Do najczęściej wymienianych powikłań należą zmiany w mózgu. Ponieważ u 90 proc. alkoholików występuje kurczenie mózgu, skutkuje to zaburzeniami równowagi, psychozą Korsakowa, uszkodzeniem komórek nerwowych, napadami padaczki i delirium. Często u alkoholika pojawiają się zmiany wątrobowe, uszkodzenie trzustki, wrzody żołądka, nowotwory jamy ustnej i odbytu. Widoczna jest też negatywna praca mięśnia sercowego $^{23}$.

Obok dolegliwości somatycznych alkoholik doświadcza zaburzeń w sferze kognitywnej. Widoczne jest to w obniżeniu sprawności intelektualnej, w braku koncentracji, zaburzeniach zapamiętywania. Alkohol wpływa też negatywnie na ludzkie emocje. Wynik tego stanowi niestabilny sposób postrzegania samego siebie. Jest to euforia, która z czasem przechodzi w stan melancholii, lęku i depresji. Dochodzi również do zahamowania rozwoju uczuciowości wyższej, stąd pojawia się prymitywizm w zachowaniu, przemoc wobec słabszych, nieposzanowanie norm życia społecznego ${ }^{24}$.

Człowiek w nałogu nie dysponuje samym sobą w sposób wolny. Potrzebuje on dawki alkoholu, aby posiadać poczucie bezpieczeństwa i zdolność do działania. Osoba uzależniona, nie będąc w stanie zerwać z nałogiem, ma poczucie osłabienia silnej woli. Dostrzega, że traci kontrolę nad własnym życiem, co związane jest z podporządkowaniem się swojemu uzależnieniu ${ }^{25}$. Alkoholik często $\mathrm{z}$ powodu nałogu doświadcza problemów związanych z wykonywaniem swojego zawodu. Nieobecność, brak wiarygodności, utrata kompetencji powodują degradację zawodową lub utratę pracy. U alkoholików postępuje zubożenie moralne. Będąc pod wpływem alkoholu, stają się

Por A. Szwedzik, Destrukcyjneskutkialkoholizmu dz cyt., s. 176-177.

Por. W. Bołoz, Uzależnienia i odpowiedzialność, dz. cyt., s. 85. 
oni sprawcami wypadków, zaprószają ogień, kontaktują się z ludźmi o podejrzanej przeszłości, stają się łatwą zdobyczą dla przestępców. Skutkiem podejmowania działań niezgodnych z prawem często mają kłopoty z wymiarem sprawiedliwości ${ }^{26}$.

Alkoholizm jest problemem nie tylko samego uzależnionego, ale także jego otoczenia. Nałóg przyczynia się do wielu konfliktów małżeńskich. Małżonkowie tworzący związek z alkoholikiem narażeni są na stosowanie przez niego przemocy fizycznej i psychicznej, doznawanie upokorzeń i przykrości. Często pobyt $\mathrm{z}$ alkoholikiem połączony jest $\mathrm{z}$ brakiem środków finansowych oraz z życiem w izolacji społecznej. Bywa tak, że związek taki albo kończy się rozwodem, albo narażony jest na wielkie trudności ${ }^{27}$.

Rodzina z osobą uzależnioną od alkoholu jest rodziną dysfunkcyjną. Brakuje w niej niezbędnych warunków do prawidłowego rozwoju dziecka. Stresogenne i patogenne sytuacje panujące w takiej wspólnocie stają się dla niego przyczyną różnych urazów psychicznych, powodujących problemy emocjonalne, zmiany w strukturze osobowości i zaburzenia w zachowaniu ${ }^{28}$. Sytuacja jest jeszcze bardziej krytyczna, gdy oboje rodzice nadużywają alkoholu. Wtedy dziecko nie znajduje w nikim oparcia ani obrony ${ }^{29}$.

Dysfunkcjonalność rodziny istotnie wpływa na dorosłe życie dzieci. Mówi się tu o tzw. syndromie DDA. Główną przyczyną stawania się dorosłym dzieckiem alkoholika jest świadomość bycia osobą porzuconą wskutek ignorowania przez rodziców lub

Por. A. Woroniecka-Borowska, M. Borowski, Alkoholizm: źródła, przejawy, drogi odzyskania nadziei, „Res Humana” 2010 nr 6, s. 28.

Por. A. Woroniecka-Borowska, M. Borowski, Alkoholizm: źródła, przejawy..., dz. cyt., S. 27.

Por. M. Chuchra, B. Śpila, Funkcjonowanie systemu rodzinnego a obraz siebie u studentów - dorosłych dzieci alkoholików (DDA), „Roczniki Nauk o Rodzinie” 10 (2010) nr 2 (57), s. 82. 
opiekunów $^{30}$. Dorosłe dziecko alkoholika ma niejako podwójną tożsamość. Z jednej strony chronologicznie jest osobą dorosłą, z drugiej strony zaś - dzieckiem, gdyż nierozwiązane problemy z dzieciństwa, nieodreagowane i wyparte urazy, brak przynależności do kogoś stanowią deficyt wpływający na dalszy, teraźniejszy i przyszły, rozwój jednostki ${ }^{31}$. Jak widać, rozwój w rodzinie z problemem alkoholowym niesie ze sobą wiele konsekwencji, które ujawniają się bardzo często dopiero w życiu dorosłym. Dzieciństwo jest bowiem kluczowym okresem dla rozwoju tożsamości człowieka ${ }^{32}$.

\section{Pomoc terapeutyczno-duszpasterska}

Pomoc wobec osoby uzależnionej jest nieodzowna, ponieważ:

Alkoholik jest chorym potrzebującym opieki medycznej oraz równocześnie pomocy na poziomie solidarności i psychoterapii. Powinny być podjęte wobec niego działania integralnie ludzkie mające na celu jego wyzwolenie ${ }^{33}$.

Aby kompetentnie pomagać, trzeba najpierw uwzględnić poszczególne fazy przebiegu choroby, przekonać alkoholika do leczenia oraz odnieść się do jego potrzeb religijnych.

Por. M. Ryś, Rodzinne uwarunkowania psychospołeczne funkcjonowania Dorosłych Dzieci Alkoholików, Warszawa 2007, s. 113-114.

31 Por. I. Jona, Zespót stresu pourazowego u DDA, [w:] Oblicza kryzysu psychologicznego i pracy interwencyjnej, red. D. Kubacka-Jasiecka, A. Lipowska-Teusch, Kraków 1997, s. 32.

32 Por. K. Chojna, Wpływ dysfunkcjonalności rodziny na dorosłe życie dzieci-syndrom DDA, „Rocznik Wydziału Pedagogicznego Wyższej Szkoły Filozoficzno-Pedagogicznej Ignatianum w Krakowie" 2009, s. 117.

33 Papieska Rada ds. Duszpasterstwa Służby Zdrowia, Karta pracowników służby zdrowia, Watykan 1995, 98. 


\subsection{Fazowy przebieg choroby alkoholowej}

Elvin Morton Jellinek wyróżnia cztery fazy przebiegu choroby alkoholowej. Pierwsze, przedalkoholowe stadium polega na piciu okazjonalnym. Trwa ono od kilku miesięcy do kilku lat. W tej fazie ma miejsce uzależnienie psychiczne od alkoholu. Najpierw pije się okazjonalnie, po to, aby doznać ulgi, a następnie robi się to już regularnie. W tym stadium dochodzi do zmniejszania się tolerancji pijącego na dyskomfort psychiczny, a zwiększa się jego tolerancja na alkohol ${ }^{34}$.

Faza druga jest fazą ostrzegawczą i trwa od sześciu miesięcy do pięciu lat. Obserwuje się tu wyraźną zmianę w reagowaniu na alkohol. Osoba zauważa, że pije częściej, inaczej i upija się po wypiciu małej ilości alkoholu. Pije nie po to, aby się rozluźnić, ale żeby zredukować zespół odstawienia. Widoczna jest chciwość alkoholu, z czym wiąże się picie szybkie, z dużą ilością alkoholu naraz. Pojawia się też picie potajemne. Głód alkoholowy prowadzi do tego, że pijący traci kontrolę nad ilością wypitego trunku i nie potrafi odmówić sobie jego spożywania aż do stanu upojenia ${ }^{35}$. W tej fazie u jednostki widoczne są problemy nawiązywania kontaktu z innymi. Towarzyszą temu takie zachowania jak: nieprzewidywalność, napady złości, okłamywanie w celu ukrycia swojego problemu alkoholowego ${ }^{36}$.

Następująca po fazie ostrzegawczej faza krytyczna charakteryzuje się utratą kontroli nad przyjmowaniem napojów alkoholowych; rozpoczyna się uzależnienie w ścisłym tego słowa znaczeniu. Nawet

Por. E. M. Jellinek, Phases of alcohol addition's, [w:] Society, culture, and drinking patterns, ed. D. J. Pittman, C. R. Sunyder, London-New York 1962, s. 360-366; E. M. Jellinek, Drinkers and alcoholics in ancient Rome, „Journal of Studies on Alcohol” 37 (1976), S. 1718-1741.

Por. T. Żurek, Medyczno-psychologiczne aspekty alkoholizmu, „Perspectiva. Legnickie Studia Teologiczno-Historyczne” 3 (2004) nr 1 (4), s. 170. 
po spożyciu niewielkiej ilości substancji pojawia się przymus pi$\mathrm{cia}^{37}$. Wydłuża się czas picia i zwiększa się ilość wypitego alkoholu. Utrata kontroli nad piciem prowadzi zawsze do nadużycia alkoholu, głębokiego upojenia, a nawet utraty przytomności. Choć pod wpływem nacisków zewnętrznych pijący może dojść do okresowej abstynencji, to jednak przy pierwszej większej okazji zaczyna pić od nowa, popadając przy tym w kilkudniowy, a nawet kilkutygodniowy „ciąg picia”. Na tym etapie można zaobserwować u pijącego gromadzenie większej ilości alkoholu i ukrywanie go w domu i pracy. Wśród objawów zauważa się zaburzenia wegetatywne, brak łaknienia, obniżenie popędu seksualnego, halucynozę alkoholową. Poza tym pijacy odseparowuje się od rodziny, zaniedbuje codzienne obowiązki, nie dotrzymuje umówionych terminów ${ }^{38}$. Coraz częściej, zwłaszcza pod koniec tej fazy, pojawia się picie już od samego rana. Jest to wyraźne pogłębienie się choroby i przejście do fazy chronicznej ${ }^{39}$.

W fazie przewlekłej zauważa się degradację fizyczną, psychiczną i moralną. „Ciągi pijackie”, czyli wielodniowe picie, powodują wyniszczenie organizmu. Upijanie się w każdym miejscu, w domu, pracy, na ulicy, przez swoją długotrwałą intensywność powoduje zatrucie organizmu, a nawet zgon spowodowany przedawkowaniem alkoholu. Jednostka traci kontrolę nad czynnościami fizjologicznymi. Pojawiają się też objawy zespołu abstynencyjnego, takie jak: bóle głowy, osłabienie, drżenie rąk, nudności, wymioty, zaburzenia nastroju, zaburzenia snu, jadłowstręt, biegunki, kołatanie serca, poty, lęki. Zrujnowanego w sensie fizjologicznym, uzależnionego od alkoholu

37 Por. S. Luft, Medycyna pastoralna, Warszawa 2002, s. 55-56; A. Woroniecka-Borowska, M. Borowski, Alkoholizm: źródła, przejawy..., dz. cyt., s. 26.

38 Por. T. Żurek, Medyczno-psychologiczne aspekty alkoholizmu, dz. cyt., s. 170.

39 Por. E. M. Jellinek, Studia nałogu alkoholowego, [w:] Wybrane spojrzenia na alkoholizm i jego leczenie, red. A. Dodziuk, Warszawa 1993, za: ]. Sokołowski, Choroba alkoholowa..., dz. cyt., s. 181-182. 
dotykają padaczka alkoholowa oraz urojenia - delirium. Aby zdobyć pieniądze na alkohol, pijący sprzedaje rzeczy własne lub rodziny, wyjmuje pieniądze ze skarbonki dziecka, posuwa się do kradzieży. W razie braku alkoholu uzależniony sięga po płyny zastępcze, np. denaturat czy płyn do mycia szyb. Podkreśla się, że dla osób znajdujących się w tej fazie są dwa wyjścia - dalej pić i umrzeć albo zgłosić się na leczenie i żyć w trzeźwości ${ }^{40}$.

\subsection{Formy pomocy terapeutycznej}

Pierwszym etapem pomocy wobec osoby uzależnionej jest interwencja, czyli przekonanie alkoholika do podjęcia leczenia. Aby leczenie było skuteczne, konieczne jest spełnienie określonych warunków. Terapeuta musi być przekonany o tym, że może pomóc pacjentowi, z kolei uzależniony jest wystarczająco umotywowany do podjęcia leczenia. Pierwszy etap leczenia obejmuje detoksykację, czyli odtrucie alkoholowe polegające na usunięciu toksycznych substancji z organizmu ${ }^{41}$. Detoksykacja obejmuje działania dwutorowe. Najpierw regeneruje organizm poprzez uzupełnienie niedoborów płynów, elektrolitów i witamin oraz mikroelementów wypłukanych przez alkohol. Następnie łagodzi objawy zespołu abstynencyjnego, czyli: lęk, drżenie, omamy, zaburzenia świadomości, bezsenność ${ }^{42}$.

Po detoksykacji pacjent jest kierowany na leczenie odwykowe. Podstawowy element kuracji stanowi terapia indywidualna i grupowa. Jej celem jest doprowadzenie do nabycia takich umiejętności, które będą pomagać pacjentowi w zachowaniu trzeźwości oraz

Por. T. Żurek, Medyczno-psychologiczne aspekty alkoholizmu, dz. cyt., s. 172-173.

Por. A. Woroniecka-Borowska, M. Borowski, Alkoholizm: źródła, przejawy..., dz. cyt., S. 28.

42 Por. http://www.leczenie-duszy.pl/detoksykacja/detoks-poalkoholowy.html (8.12.2015). 
długotrwałym procesie zdrowienia. Psychoterapia ma przywrócić choremu zdolności do życia bez alkoholu w taki sposób, aby znów poczuł się wolnym i godnym szacunku w oczach własnych i swoich bliskich $^{43}$. Do najważniejszych zadań psychoterapii należy zaliczyć: 1) zwiększenie motywacji do utrzymania abstynencji, 2) przywrócenie zdolności do rozwiązywania problemów osobistych, 3) nauczenie zdrowego i konstruktywnego życia, 4) usunięcie zaburzeń somatycznych i psychicznych ${ }^{44}$.

Biorąc pod uwagę aspekt temporalny psychoterapii, należy podkreślić, że zasadniczo trwa ona około dwóch lat i składa się z terapii podstawowej i pogłębionej. Terapia podstawowa ${ }^{45}$ polega na wypracowaniu sprawności zachowania abstynencji. Pacjent winien się nauczyć właściwej organizacji dnia, asertywnego odmawiania picia, umiejętności radzenia sobie z głodem alkoholowym, nawiązania nowych kontaktów z ludźmi, aby tworząc interakcje, wytrwać w trzeźwości. Etap ten trwa od sześciu do ośmiu tygodni w oddziałach stacjonarnych. Uzależniony uczestniczy wtedy $\mathrm{w}$ zajęciach grupowych i indywidualnych prowadzonych przez terapeutę ${ }^{46}$.

Terapia pogłębiona uczy chorego, jak zatrzymać nałóg i jak wypracować zdrowe sposoby rozwiązywania trudności. Etap ten przebiega $\mathrm{w}$ warunkach ambulatoryjnych. Pacjent pozostaje w kontakcie indywidualnym z terapeutą oraz uczęszcza raz w tygodniu na spotkania grupy terapeutycznej. Zarówno w czasie całej terapii, jak i po jej

43 Por. A. Woroniecka-Borowska, M. Borowski, Alkoholizm: źródła, przejawy..., dz. cyt., S. 29.

44 Por. J. Kaczmarczyk, Wspólnota anonimowych alkoholików w Polsce, Warszawa 2008, s. 47.

45 Por. C. Cekiera, Poradnictwo uzależnień, [w:] Poradnictwo psychologiczno-religijne, red. ]. Makselon, Kraków 2001, s. 179-180; C. Cekiera, Alkoholizm, dz. cyt., s. 35-36.

46 Por. J. Wołoszyn, Pomoc psychoterapeutyczna osobom uzależnionym od alkoholu, dz. cyt., s. 138. 
zakończeniu wskazany jest kontakt z grupami samopomocowymi, takimi jak wspólnoty Anonimowych Alkoholików czy kluby abstynenckie ${ }^{47}$.

Z psychoterapią ściśle połączona jest socjoterapia. Jej zadanie to wprowadzenie pacjenta na powrót do społeczności osób w najbliższym i szerszym otoczeniu. Istotne jest także przywrócenie mu nawyku pracy. Może się z tym wiązać podwyższenie kwalifikacji zawodowych, aby w ten sposób przywrócić większe zainteresowanie wykonywanymi czynnościami i umożliwić awans w hierarchii zawodowej. Dla uzależnionego ważne mogą okazać się także spotykania w tzw. grupach partnerskich w celu wymiany osobistych doświadczeń. Najczęściej są to grupy nieformalne tworzone w celu wzajemnego wspierania się i udzielania sobie pomocy. Fundamentalne znaczenie dla walki z alkoholizmem mają działania o charakterze profilaktycznym. Należą do nich kampanie społeczne mówiące o szkodliwości alkoholu czy propagowanie kultury abstynencji, np. wesel bezalkoholowych ${ }^{48}$.

\subsection{Wsparcie duszpasterskie}

Kościół nie zapomina o osobach uzależnionych od alkoholu. Rodzinom i środowiskom będącym ofiarami alkoholizmu proponuje terapię miłości. Terapię tę obrazuje ewangeliczna przypowieść o miłosiernym Samarytaninie. Uzależnieni, zwłaszcza młodzi, przypominają niekiedy bohatera ewangelicznej przypowieści, który został napadnięty przez zbójców, ograbiony i na wpół umarły pozostawiony

47

Por. ]. Wołoszyn, Pomoc psychoterapeutyczna osobom uzależnionym od alkoholu, dz. cyt., s. 138-139; D. Kołodziej, Alkohol w wieku podeszłym: specyfika problemu, „Społeczeństwo i Rodzina” 2010 nr 22, s. 177.

48 Por. A. Woroniecka-Borowska, M. Borowski, Alkoholizm: Źródła, przejawy..., dz. cyt., s. 29; W. Wietkamp, Alkoholismus, [w:] Lexikon für Theologie und Kirche, 3. Aufl., Bd. 1, 1993, s. 396-397. 
na drodze do Jerycha (por. Łk 10, 29-37). Ofiary narkomanii i alkoholizmu są ludźmi w drodze, poszukującymi czegoś, co jest im potrzebne, by mogli żyć, jednak napotykającymi handlarzy śmierci, którzy proponują im złudne wizje wolności i fałszywe obietnice szczęścia. Alkohol i narkotyki ograbiają człowieka z najcenniejszych wartości, zadają mu głębokie rany cielesne i duchowe, łamią sumienie i poniżają osobową godność. Jan Paweł II podkreślał, że wobec osób uzależnionych każdy chrześcijanin powinien upodobnić się do dobrego Samarytanina, który potrafi stać się bliźnim dla ludzi zmagającymi się z trudnościami ${ }^{49}$.

Pomoc samarytańska wyraża się w konkretnych działaniach. Chodzi najpierw o wyszukanie rodzin dotkniętych alkoholizmem. W akcję rozpoznawania środowiska i w organizowanie pomocy powinni włączyć się oprócz duszpasterzy liderzy grup parafialnych, tacy jak członkowie Parafialnej Rady Duszpasterskiej i Ekonomicznej, nadzwyczajni szafarze Komunii Świętej oraz członkowie ruchów, wspólnot i stowarzyszeń kościelnych ${ }^{50}$.

Rodzinom alkoholików nierzadko potrzebna jest porada prawna, pomoc psychologiczna i moralno-duchowa. Nieodzowne jest też ich wsparcie materialne, organizowanie świetlic terapeutycznych czy choćby sponsorowanie dzieciom obiadów w stołówkach szkolnych. W parafiach i dekanatach konieczne wydaje się działanie poradni i zespołów wsparcia, pomagających w sytuacjach kryzysowych. W diecezjach ważne są ośrodki terapeutyczne dla rodzin alkoholików, gdzie pracują profesjonalnie przygotowani do takiej posługi duszpasterze

Jan Paweł II, Przesłanie Ojca Świętego do uczestników Międzynarodowej Konferencji na temat Problemów Narkomanii i Alkoholizmu zorganizowanej przez Radę Pontyfikalna do spraw Pomocy Duszpasterskiej Pracownikom Służby Zdrowia; Watykan, 21-23 listopada 1991, [W:] W trosce o życie. Wybrane dokumenty Stolicy Apostolskiej, red. K. Szczygieł, Tarnów 1998, s. 227, 2-4.

50 Por. W. Śmigiel, Pomoc Kościoła ludziom uzależnionym od alkoholu, „Ateneum Kapłańskie" 146 (2006) z. 3 (583), s. 464. 
i terapeuci ${ }^{51}$. W wymiarze duchowym istotne jest tutaj odbudowanie więzi z Bogiem i ludźmi.

Duszpasterstwo trzeźwości winno współpracować z ruchami samopomocowymi Anonimowych Alkoholików. Proponuje się tutaj 12 kroków $\mathrm{AA}^{52}$. Choć program ten nie jest religijny, to jednak sprawdził się jako skuteczna metoda pracy zawierająca w sobie chrześcijańską wizję budowania komunii z Bogiem i człowiekiem ${ }^{53}$. Zmiany postaw u alkoholików dokonują się zwykle dzięki: 1) samopomocy opierającej się na poznawaniu i stosowaniu wspomnianych 12 kroków, 2) pomocy poszczególnych członków grupy AA, 3) wsparciu innych osób mających taki sam problem. W ostatnich latach w oparciu o dorobek wspólnot AA powstały także grupy wspierające rodziny z problemem alkoholowym (Al-Anon), grupy wsparcia dla dzieci i młodzieży z rodzin alkoholowych (Al-Ateen, Alakid), a także grupy Dorosłych Dzieci Alkoholików ${ }^{54}$.

Duszpasterz pomagający uzależnionym winien pamiętać, że

nie można zwalczać alkoholizmu czy narkomanii, leczyć i skutecznie uzdrawiać ofiar nałogów, dopóki nie odbuduje się takich wartości moralnych jak miłość i sens życia - jedynych nadających prawdziwy sens naszej egzystencji, szczególnie jeśli opromienione są światłem wiary ${ }^{55}$.

Por. W. Śmigiel, Pomoc Kościoła ludziom uzależnionym od alkoholu, dz. cyt., s. 464.

Por. J. K. Gierowski, Z. Lew-Starowicz, J. Mellibruda, Psychopatologia zjawisk społecznych, [w:] Psychologia. Podręcznik akademicki, t. 3, red. ]. Strelau, Gdańsk 2000, s. 193-194.

Por. A. Baran, Bóg w doświadczeniu Anonimowych Alkoholików, [w:] Duchowa terapia osób uzależnionych, red. A. Baran, Warszawa 2006, s. 15-49; P. Kulbacki, Komunia z Bogiem źródłem i owocem trzeźwości, „Łódzkie Studia Teologiczne” 19 (2010), s. 115.

Por. A. Szwedzik, Destrukcyjne skutki alkoholizmu..., dz. cyt., s. 183-184; A. M. Arendarczyk, Codzienność i odświętność w rodzinie z problemem alkoholowym widziana przez pryzmat doświadczeń Dorosłych Dzieci Alkoholików, „Socjologia Religii” 7 (2009), s. 29-45.

Jan Paweł II, Przesłanie Ojca Świętego do uczestników..., dz. cyt., s. 227, 2-4. 


\section{Wychowanie do trzeźwości}

Zachowanie trzeźwości jest najbardziej skuteczną drogą do walki $\mathrm{z}$ alkoholizmem.

Trzeźwość jest koniecznym warunkiem rozwoju poszczególnych osób, rodzin i środowisk. Jest warunkiem budowania społeczeństwa żyjącego w wolności wewnętrznej i ładzie moralnym. Jest podstawą ochrony życia, zdrowia i godności ludzkiej ${ }^{56}$.

Niebezpieczeństwo alkoholizmu tkwi w tym, że

odbiera on godność, poczucie odpowiedzialności, jasne widzenie rzeczywistości. On przekreśla świat wartości osobowych, narodowych i religijnych. On staje się narzędziem zniewolenia i wyniszczenia nie tylko poszczególnych rodzin, lecz także bytu narodu ${ }^{57}$.

\subsection{Powinność trzeźwości}

Biblia bardzo krytycznie ocenia pijaństwo. Zdaniem Starego Testamentu powoduje ono brak panowania nad sobą, pozbawia człowieka rozumu (Iz 29, 10), doprowadza do bezbożności (Iz 5, 12), nierządu $(\mathrm{Oz} 4,11 n)$ i zaniedbywania obowiązków (Prz 31, 4n); przynosi wstyd (Ha 2, 15 n) i hańbę (Rdz 9, 21). Pijak skazany jest na ubóstwo (Prz 21, 17), rozpustę (Syr 19, 2) i na nieuczciwość w słowach

56 List pasterski Episkopatu Polski w zwiqzku z sierpniowym wezwaniem do trzeźwości, „Kronika Diecezji Sandomiersko-Radomskiej” 84 (1991), s. 151, za: J. Krasiński, Działalność Kościoła katolickiego w Polsce w dziedzinie trzeźwości, „Studia Theologica Varsaviensia" 36 (1998) nr 2, s. 149.

57 Wezwanie Episkopatu Polski do wzmożenia odpowiedzialności za trzeźwość narodu, „Kronika Diecezji Sandomiersko-Radomskiej” 79 (1986), s. 200, za: J. Krasiński, Dziatalność Kościoła katolickiego w Polsce w dziedzinie trzeźwości, dz. cyt., s. 149. 
(Prz 23, 30-35). Święty Paweł podkreśla, że pijący nie odziedziczą Królestwa Bożego (1 Kor 6, 9-10) ${ }^{58}$.

Powodujące brak panowania nad sobą pijaństwo zostało bardzo negatywnie ocenione przez Biblię. Alternatywę może stanowić jedynie trzeźwość. To ona jest właściwą postawą chrześcijańską i cnotą o wielkim znaczeniu moralnym. Trzeźwość uzdalnia do walki z grzechem (1 Kor 15, 34), czyni czujnym na niespodziewane ataki Szatana (1 $\mathrm{P} 5,8)$, przygotowuje w duszy miejsce na nawiedzenie Ducha Świętego (Ef 5, 18), ułatwia oczekiwanie na drugie przyjście Chrystusa ${ }^{59}$.

Do trzeźwości wzywa św. Augustyn. Przestrzega on przed pijaństwem w następujących słowach: „Kiedy zwierzęta prowadzi się do wody, aby mogły ugasić pragnienie, to nie chcą one pić więcej niż trzeba. Niech zatem zważą pijacy, czy nie są gorsi od zwierząt”. Bardzo mocno formułuje swoją krytykę wobec pijaństwa św. Jan Chryzostom. Mówi on, że pijaństwo jest „wielorakim i wielokształtnym dzikim zwierzęciem [...] mającym wiele głów; stąd pochodzą: cudzołóstwo, gniewy, zwyrodnienia, brzydkie mowy"60.

Do unikania wszelkiego rodzaju nadużyć związanych ze spożywaniem alkoholu zobowiązuje Katechizm Kościoła katolickiego ${ }^{61}$. Z punktu widzenia etyki chrześcijańskiej alkoholizm uwłacza godności osoby ludzkiej, obniża poziom życia umysłowego i moralnego oraz wrażliwości religijnej. Nałóg ten jest też powodem wielu wykroczeń przeciwko moralnym zasadom życia rodzinnego, społecznego i gospodarczego ${ }^{62}$. Nadużywanie alkoholu zasługuje na potępienie: S. 200-201. S. 205. S. 207.

Por. M. Majewski, Używanie napojów alkoholowych zagadnieniem moralnym, dz. cyt., Por. M. Majewski, Używanie napojów alkoholowych zagadnieniem moralnym, dz. cyt.,

Por. M. Majewski, Używanie napojów alkoholowych zagadnieniem moralnym, dz. cyt.,

Por. Kongregacja Nauki Wiary, Katechizm Kościoła katolickiego, Poznań 1994, 2290. Por. M. Lisowski, Alkoholizm, [w:] Encyklopedia katolicka, t. 1, Lublin 1989, s. 374. 
„alkoholizm, który powoduje uzależnienie, przyćmiewa sumienie i w fazie chronicznej powoduje poważne szkody w organizmie i umyśle"63.

Jan Paweł II, przemawiając do uczestników Międzynarodowej Konferencji na temat Problemów Narkomanii i Alkoholizmu w 1991 roku, podkreślił, że zarówno narkomania, jak i alkoholizm są przeciwne życiu. Papież stwierdził:

Nie można mówić o wolności narkotyzowania się ani o prawie do narkotyków, ponieważ istota ludzka nie ma prawa szkodzić samej sobie, nie może i nie powinna nigdy pozbawiać się osobowej godności danej jej przez Boga ${ }^{64}$.

Przestrzegając przed alkoholizmem i narkomanią, papież z wielką troską prosił ludzi młodych:

Nie ulegajcie ich pokusom. Po cóż wchodzić na drogę, która prowadzi donikąd? Dlaczego mielibyście rezygnować ze stopniowego osiągania dojrzałości i godzić się na przedwczesną starość? Po cóż marnować życie i siły, które przecież mogą znaleźć radosną afirmację w ideałach uczciwości, pracowitości, poświęcenia, czystości, miłości ${ }^{65}$.

\subsection{Duszpasterska formacja do trzeźwości}

Kościół zabiega o rozwój duchowy człowieka. Rozwój ten wymaga trzeźwości. Dotyczy on wszystkich etapów życia. W przypadku dzieci i młodzieży zachowanie trzeźwości jest związane z całkowitą abstynencją. U dorosłych spożywanie alkoholu nie powinno mody-

\footnotetext{
63 Papieska Rada ds. Duszpasterstwa Służby Zdrowia, Karta pracowników służby zdrowia, dz. cyt., 97.

64 Jan Paweł II, Przesłanie Ojca Świętego do uczestników..., dz. cyt., s. 228, 2-3.

65 Jan Paweł II, Przesłanie Ojca Świętego do uczestników..., dz. cyt., s. 228-229, 4.
} 
fikować ich zachowania. Niekiedy występują sytuacje, kiedy dorośli są także zobowiązani do abstynencji (obowiązki stanu, wychowawcy, kierowcy) ${ }^{66}$. Kościół proponuje również dorosłym abstynencję, podejmowaną z miłości i rozumianą jako dar będący radykalnym świadectwem ewangelicznym.

Ważną rolę w duszpasterstwie odgrywa wychowanie do trzeźwości. Jest to tworzenie zwyczajów zachowywania abstynencji przy ważnych uroczystościach rodzinnych, np. pierwsza komunia święta czy bierzmowanie. Zobowiązania abstynenckie podejmowanie wtedy przez dzieci i młodzież mają bardzo istotne znaczenie formacyjne, zwłaszcza wtedy, kiedy rodzice towarzyszą dzieciom w procesie dojrzewania w wierze, paralelnemu do rozwoju osobowościowego ${ }^{67}$. Czytelnym znakiem sprzeciwu wobec nadużywania alkoholu jest również urządzanie wesel bezalkoholowych.

Do inicjatyw na rzecz krzewienia trzeźwości niewątpliwie należy zaliczyć Tydzień Modlitw o Trzeźwość Narodu ${ }^{68}$, którego egzemplifikacją jest deklarowana wśród jakiejś grupy katolików abstynencja w adwencie, wielkim poście i w sierpniu. W trzeźwościowym duszpasterstwie parafialnym niemałą rolę odgrywa parafialna księga trzeźwości. Do wpisu do niej można zachęcać zwłaszcza w okresie wielkiego postu, z okazji rekolekcji oraz innych okazji związanych z wydarzeniami rodzinnymi, parafialnymi czy osobistymi. Osoby, które zadeklarowały czasową lub stałą abstynencję, mogą tworzyć

Por. M. Dziewiecki, Duszpasterstwo trzeźwości a duszpasterstwo alkoholików, [w:] Nowe przesłanie nadziei. Podręcznik duszpasterstwa trzeźwości, red. M. Dziewiecki, Warszawa 2000, s. 232.

Por. P. Kulbacki, Komunia z Bogiem źródłem i owocem trzeźwości, „Łódzkie Studia Teologiczne" 19 (2010), s. 110; M. Dziewiecki, Abstynencja dzieci troskq rodziny, Kościoła i Narodu, „Zeszyty Formacji Katechetów” 2015 nr 2 (58), s. 6-9.

Por. T. Syczewski, Sprawozdanie z jesiennej sesji Zespołu ds. Apostolstwa Trzeźwości przy Konferencji Episkopatu Polski i diecezjalnych duszpasterzy trzeźwości oraz zakonnych referentów i asystentów trzeźwości, Zakroczym 20 listopada 1998 roku, "Studia Teologiczne. Białystok, Drohiczyn, Łomża” 17 (1999), s. 406. 
parafialny apostolat trzeźwości. Istotną rolę w krzewieniu trzeźwości pełnią ruchy trzeźwościowe. Wśród tych ważnych trzeba wymienić: ruch Odnowy w Duchu Świętym, neokatechumenat, ruch Domowego Kościoła, kluby abstynenta oraz takie bractwa trzeźwości jak: bractwo Anioła Stróża, koło św. Stanisława czy koła św. Kazimierza ${ }^{69}$.

Na szczególne wyróżnienie zasługuje Ruch Trzeźwości im. św. Maksymiliana Kolbego. Do jego głównych zadań należy troska o pogłębienie wiary i moralności przez propagowanie abstynencji i trzeźwości oraz wolności od innych uzależnień. Trzeźwość jest integralną częścią życia, dlatego do najważniejszych celów ruchu zalicza się: 1) pozyskiwanie jak największej liczby zwolenników abstynencji i trzeźwości, 2) organizowanie nabożeństw i konferencji propagujących trzeźwość, 3) zachęcanie do organizowania uroczystości rodzinnych i publicznych bez alkoholu, 4) rozprowadzanie materiałów poświęconych tematyce trzeźwości i pokazujących zagrożenia związane z uzależnieniami, 5) współpracę z przychodniami zdrowia i zakładami odwykowymi ${ }^{70}$.

Popularnym programem wychowującym do trzeźwości jest Krucjata Wyzwolenia Człowieka, zainicjowana przez ks. Franciszka Blachnickiego i Ruch Światło-Życie. Zaleca się w niej wykonywanie czynów miłosierdzia, rozumianych jako modlitwa, post i jałmużna. Post jest tu praktykowany m.in. w formie abstynencji od alkoholu, która ma być skutecznym środkiem pomagającym w przełamaniu powszechnego zwyczaju namawiania do picia. Celem Krucjaty nie jest ilościowe upowszechnienie abstynencji, ale ograniczenie nadużywania alkoholu według zasady: „przez abstynencję niektórych do umiarkowania wielu”. Dobrowolnie podjęta abstynencja przyczynia się do wewnętrznej wolności i sprzyja rozwojowi dojrzałej osobo-

69 Por. J. Krasiński, Działalność Kościoła katolickiego..., dz. cyt., s. 156-163.

70 Por. J. Krasiński, Działalność Kościoła katolickiego..., dz. cyt., s. 161-162. 
wości. Ma ona również znaczenie terapeutyczne. Niepijący bowiem twórczo wspomagają tych, którzy nie radzą sobie $\mathrm{z}$ alkoholem ${ }^{71}$.

Działalność na polu trzeźwości ułatwia sama abstynencja duszpasterza. Przykładem mogą tu być: król Salomon, prorok Samuel i Jan Chrzciciel. Mężowie ci, aby wykonywać jak najskuteczniej swoją misję, całkowicie poświęcili się Bogu, ślubując powstrzymywanie się od spożywania wszelkich, pochodzących z winnicy produktów ${ }^{72}$. Kapłan poprzez swoją abstynencję zdobywa siłę duchową i może dzięki temu bardziej i wiarygodniej przestrzegać przed skutkami związanymi z nadużywaniem alkoholu. Nie naraża się też na zarzut, że „ksiądz przecież też pije”, ale poprzez swój dystans do alkoholu tworzy kulturę trzeźwości i kształtuje trzeźwościowe postawy.

Oprócz zalecanej abstynencji duszpasterz powinien dysponować podstawową wiedzą dotyczącą problemów alkoholowych. Przygotowanie do kapłaństwa winno obejmować więc te zagadnienia, które odnoszą się do przyczyn i skutków alkoholizmu, a także informacje o placówkach terapeutycznych, do których może być skierowany potrzebujący pomocy parafianin. Kapłan powinien posiadać również podstawową wiedzę na temat uzależnieńn ${ }^{73}$.

\section{Zakończenie}

Alkoholizm dotyka dziś wielu ludzi. Jest on problemem nie tylko indywidualnym, ale także rodzinnym i społecznym. Do ukształtowania się tzw. osobowości przednałogowej dochodzi już w środowisku rodzinnym. Alkoholicy najczęściej pochodzą z rodzin dotkniętych

Por. M. Załuska i in., Znaczenie podjęcia Krucjaty Wyzwolenia Człowieka dla osobistego rozwoju jej uczestników oraz dla funkcji wychowawczej rodziny w zakresie wychowania do trzeźwości, „Studia nad Rodziną” 2003 nr 7/1, s. 174. Por. M. Majewski, Używanie napojów alkoholowych zagadnieniem moralnym, dz. cyt., S. 213.

73 Por. Teologia pastoralna, t. II, red. R. Kamiński, Lublin 2002, s. 131. 
przez alkohol. Nadużywanie tej substancji wywołuje wiele dolegliwości somatycznych i psychicznych. Nałóg jest także powodem licznych konfliktów małżeńskich i rodzinnych. W wielu przypadkach alkoholizm prowadzi do rozpadu małżeństwa, a rodzina borykająca się z tym problemem nie zapewnia dziecku niezbędnych warunków do prawidłowego rozwoju. Dysfunkcjonalność rodziny negatywnie wpływa na dorosłe życie dzieci, które dotknięte są syndromem DDA.

Każdy alkoholik wymaga leczenia. Obejmuje ono najpierw detoksykację, a później leczenie odwykowe. Psychoterapia ma pomóc choremu funkcjonować w sposób wolny bez alkoholu, wypracować zdrowe sposoby rozwiązywania trudności, umotywować do podjęcia pracy oraz przywrócić mu utraconą godność. Na terapii poleca się także kontakt z grupami samopomocowymi Anonimowych Alkoholików.

Dla człowieka religijnego nie bez znaczenia jest wsparcie duszpasterskie. Kościół pamięta o uzależnionych od alkoholu i proponuje im, wyrażającą się w konkretnych działaniach, terapię miłości. Chodzi tu o wsparcie materialne rodziny, pomoc psychologiczną i moralno-duchową, odbudowanie więzi z Bogiem i ludźmi. Każde duszpasterstwo trzeźwości winno współpracować z ruchami samopomocowymi Anonimowych Alkoholików.

Ważną rolę w duszpasterstwie odgrywa wychowanie do trzeźwości. Istotne znaczenie formacyjne ma zalecana abstynencja dzieci i młodzieży oraz tworzenie zwyczajów zachowywania abstynencji przy ważnych uroczystościach rodzinnych, np. pierwsza komunia święta czy bierzmowanie. Krzewienie trzeźwości dokonuje się poprzez takie inicjatywy duszpasterskie jak: Tydzień Modlitw o Trzeźwość Narodu, zachęcanie do abstynencji w adwencie, wielkim poście i w sierpniu. Nie można nie zauważyć prężnie działających inicjatyw na rzecz trzeźwości. Są to: Ruch Trzeźwości im. św. Maksymiliana Kolbego oraz Krucjata Wyzwolenia Człowieka.

Omówiona problematyka wsparcia psychologiczno-pastoralnego dotycząca uzależnienia od alkoholu wydaje się bardzo aktualna. 
Człowiek uzależniony żyje bowiem zawsze w jakiejś wspólnocie. Kiedy o pomoc w tej sprawie zwraca się rodzina albo sam nadużywający alkoholu, często na początku prośba o wsparcie kierowana jest do parafii i duszpasterza. Kompetencje duszpasterza nie zawsze wystarczają, aby udzielić fachowej pomocy, dlatego jest wtedy konieczne, aby kapłan wskazał konkretny ośrodek, który może poprzez leczenie farmakologiczne i psychoterapię przywrócić chorego do zdrowia. Leczenie, zwłaszcza w sytuacji człowieka wierzącego, potrzebuje wsparcia duchowego i aksjologicznego, dlatego pomoc medyczno-psychologiczna i duszpasterska nawzajem się uzupełniają i tworzą spójny system wsparcia. 